\title{
Pengaruh Debt to Equity Ratio, Return On Equity, Earning Per Share Terhadap Price Earning Ratio pada Perusahaan Sektor Otomotif yang Terdaftar Di Indeks Saham Syariah Indonesia (ISSI) Tahun 2013-2017
}

\author{
Lailatul Musyarrofah \\ Program Studi akuntansi Syariah, Fakultas EkonomiBisnis Islam , IAIN Madura, Indonesia \\ lailatul_m@gmail.com \\ Lely Shofa Imama \\ Program Studi akuntansi Syariah, Fakultas EkonomiBisnis Islam , IAIN Madura, Indonesia \\ lely_she@yahoo.com
}

\begin{abstract}
:
In measuring the level of company confidence in investment activities, analysis can be carried out. One of the financial ratio analyzes that can be used to measure stocks is the Price Earning Ratio approach. This study aims to test empirically the effect of Debt To Equity Ratio, Return On Equity, Earning Per Share on Price Earning Ratio in automotive companies listed on the Indonesian Sharia Stock Index, either simultaneously or partially. The period used in this research is 5 (five) years, starting from 2013 to 2017. This research uses quantitative methods with three independent variables and one dependent variable. Popolation in this study is an automotive company listed on the Indonesian Sharia Stock Index 2013-2017. The sample in this study used purposive sampling method. Based on the criteria found, 8 companies were the research samples. The data analysis technique used is multiple linear regression using secondary data. Based on the results of data analysis, it shows that the independent variables simultaneously have a significant effect on the dependent variable as evidenced by Fcount 3.083> Ftable 2.90, a test which states that the variable that has a negative effect on Price Earning Ratio (PER) is the Debt to Equity Ratio (X1) Thitung amounting to 2,087. Meanwhile, the variables that have no effect on Price Earning Ratio (PER) are Return On Equity (X2) Tcount of -0.571 and Earning Per Share (X3) Tcount of 0.125 . The adjusted R-square value is 0.168 which shows the ability of the independent variable $(\mathrm{X})$ used in this study which includes Return On Equity (X1), Debt to Equity Ratio (X2), and Earning Per Share (X3) to explain the dependent variable (Y) namely Price Earning Ratio of $24.8 \%$, the remaining $75.2 \%$. variables not included in the model such as stock market prices, liquidity levels, investment risk, and macroeconomic factors such as inflation.

Keywords: Debt To Equity Ratio (DER); Return On Equity (ROE); Earning Per Share (EPS); Price Earning Ratio (PER)..
\end{abstract}

\begin{abstract}
Abstrak:
Dalam mengukur tingkat keberhasilan perusahaan dalam aktifitas investasi dapat dilakukan analisis. Salah satu analisis rasio keuangan yang dapat digunakan untuk melakukan penilaian saham adalah pendekatan Price Earning Ratio. Penelitian ini bertujuan untuk menguji secara empiris pengaruh Debt To Equity Ratio, Return On Equity, Earning Per Share terhadap Price Earning Ratio pada perusahaan Otomotif yang terdaftar di Indek Saham Syariah Indonesia baik secara simultan maupun parsial. Periode yang digunakan dalam penelitian ini adalah 5 (lima) tahun, yaitu mulai dari tahun 2013 sampai 2017. Penelitian ini menggunakan metode kuantitatif dengan tiga variable Independen dan satu variable dependen. Popolasi dalam penelitian ini adalah perusahaan otomotif yang terdaftar di Indek Saham Syariah Indonesia tahun 2013-2017. Sampel dalam penelitian ini menggunakan metode Purposive sampling. Berdasarkan kriteria yang ada didapatkan 8 perusahaan yang menjadi sampel penelitian. Tekhnik analisis data yang digunakan adlah regresi linier berganda dengan menggunakan data sekunder. Berdasarkan hasil analisis data, disimpulkan bahwa variabel independen secara simultan berpengaruh signifikan terhadap variabel dependen dibuktikan dengan $\mathrm{F}_{\text {hitung }}$
\end{abstract}


$3,083>\mathrm{F}_{\text {tabel }} 2,90$, pengujian menyatakan bahwa variabel yang berpengaruh negatif terhadap Price Earning Ratio (PER) adalah Debt to Equity Ratio (X1) Thitung sebesar 2,087. Sedangkan variabel yang tidak berpengaruh terhadap Price Earning Ratio (PER) adalah Return On Equity (X2) $\mathrm{T}_{\text {hitung }}$ sebesar -0,571 dan Earning Per Share (X3) $\mathrm{T}_{\text {hitung }}$ sebesar -0,125. Nilai adjusted R-square sebesar 0,168 yang menunjukkan kemampuan variabel independen (X) yang digunakan dalam penelitian ini yang meliputi Return On Equity (X1), Debt to Equity Ratio (X2), dan Earning Per Share (X3) dapat menjelaskan variabel dependen (Y) yaitu Price Earning Ratio sebesar $24,8 \%$, sisanya yaitu sebesar 75,2\% dijelaskan oleh variabel yang tidak masuk dalam model seperti harga pasar saham, tingkat likuiditas, risiko investasi, dan faktor ekonomi makro seperti inflasi.

Kata Kunci: Debt To Equity Ratio (DER); Return On Equity (ROE); Earning Per Share (EPS); Price Earning Ratio (PER) 


\section{PENDAHULUAN}

Pasar modal merupakan salah satu acuan untuk melihat tentang kegairahan atau dinamisnya bisnis Negara dan ukuran untuk melihat kemajuan perekonomian Negara yang bersangkutan. Keberadaan pasar modal di suatu negara menggambarkan betapa besarnya perhatian pemerintah negara tersebut untuk ikut serta mendongkrak naiknya tingkat pertumbuhan ekonomi. ${ }^{1}$

Dalam ukuran pasar, Indonesia merupakan pasar mobil terbesar di Asia Tenggara dan Wilayah ASEAN, menguasai sekitar sepertiga dari total penjualan mobil tahunan di ASEAN. Industri Otomotif Indonesia telah menjadi sebuah pilar penting dalam sektor manufaktur. Karena, banyak perusahaan mobil yang terkenal di dunia membuka pabrik-pabrik manufaktur mobi atau meningkatkan kapasitas produksinya di Indonesia. Pemerintah terus mendorong industry otomotif Indonesia untuk terus tumbuh.Pemerintah bertekad untuk mengubah Indonesia menjadi pusat produksi mobil terbesar di Asia Tenggara di Wilayah ASEAN. ${ }^{2}$

Dukungan pasar modal bagi dunia usaha akan memperkokoh struktur permodalannya karena dunia usaha dapat mengatur kombinasi sumber pembiayaan yang sedemikian rupa, sehingga mencerminkan perpaduan sumber pembiayaan jangka panjang. ${ }^{3}$

Indonesia sebagai negara muslim terbesar di dunia merupakan pasar yang sangat besar untuk mengembangkan industri keuangan syariah. Investasi syariah di pasar modal yang merupakan bagian dari industri keuangan syariah mempunyai peranan yang cukup penting untuk dapat meningkatkan pangsa pasar industri keuangan syariah di Indonesia. Meskipun perkembangannya relatif baru di bandingkan dengan perbankan syariah maupun asuransi syariah tetapi seiring dengan pertumbuhan yang signifikan di industri pasar modal Indonesia. ${ }^{4}$

Meskipun di Indonesia gaung pengetahuan dan penerimaan pasar modal belum sebaik di Negara-negara maju, namun harus diakui bahwa jika dirunut kurun waktu selama ini, pasar modal telah mengalami perkembangan yang cukup signifikan.Hal ini terbukti dengan semakin banyak jumlah sekuritas yang diperdangkan dengan kapitalisasi pasar cukup besar, Peran pasar modal dalam perkembangan industry-industri di berbagai sektor. ${ }^{5}$

Pembentukan harga saham terjadi karena adanya permintaan dan penawaran atas saham tersebut. Dengan kata lain harga saham terbentuk oleh Supply dan demand atas saham tersebut. Supply dan demand terjadi karena adanya banyak faktor, baik yang sifatnya spesifik atas saham tersebut (kinerja perusahaan dan industri dimana perusahaan tersebut bergerak) maupun faktor yang sifatnya makro seperti tingkat suku bunga, inflasi, nilai tukar dan faktorfaktor non ekonomi seperti kondisi sosial, politik dan faktor lainnya. ${ }^{6}$

Harga saham di bursa ditentukan oleh kekuatan pasar, yang berarti harga saham tergantung dari kekuatan permintaan dan penawaran. Kondisi permintaan dan penawaran atas saham yang fluktuatif tiap harinya akan membawa pola harga saham yang fluktuatif juga.

\footnotetext{
${ }^{1}$ Irham fahmi, Manajemen Keuangan Perusahaan.(Jakarta:Mitra Wacana Media, 2004),hlm. 305

${ }^{2}$ https://www.indonesia-investments.aom/id/bisnis/industri-sektor/otomotif/item6047 diakses pada 08 Oktober 2018

3 Tavinayati, Yulia Qamariyanti, Hukum Pasar Modal Indonesia, (Jakarta: Sinar Grafika, 2013), Hlm. 6

${ }^{4}$ PT. Bursa Efek Indonesia, 2018

5 Nor Hadi, Pasar Modal (Acuan Teoritis dan Praktis Investasi di Instrumen Keuangan Pasar Modal), (Yogyakarta: Graha ilmu, 2013), hlm. 10

${ }^{6}$ www.idx.co.id diakses pada 15 Oktober 2018
} 
Pada kondisi dimana permintaan saham lebih besar, maka harga saham akan cenderung naik. Sedangkan, pada kondisi dimana penawaran saham lebih banyak maka harga saham akan menurun. ${ }^{7}$

Pergerakan harga saham yang terjadi di bursa efek merupakan suatu fenomena yang sangat menarik bagi para investor untuk dilakukan suatu analisa. Sebab suatu pergerakan harga saham yang wajar akan menumbuhkan suatu kepercayaan pada diri investor dalam melakukan investasinya untuk membeli atau menjual saham yang ada. Pergerakan penjualan mobil dan motor memengaruhi pergerakan saham emiten-emiten otomotif di antaranya PT Astra International Tbk. (ASII) dan PT Indomobil Sukses Internasional Tbk. (IMAS) juga ikut melorot. Per 3 Januari 2014, saham ASII masih tercatat Rp6.750 per saham.Namun sampai dengan 1 Januari 2016, harga saham ASII anjlok 11 persen menjadi Rp6.000 per saham. Dalam kurun waktu dua tahun itu, harga terendah ASII sempat berada di level Rp5.125 per saham. ${ }^{8}$

Gambar 1

Pergerakan Harga Saham Otomotif Tahun 2013-2017

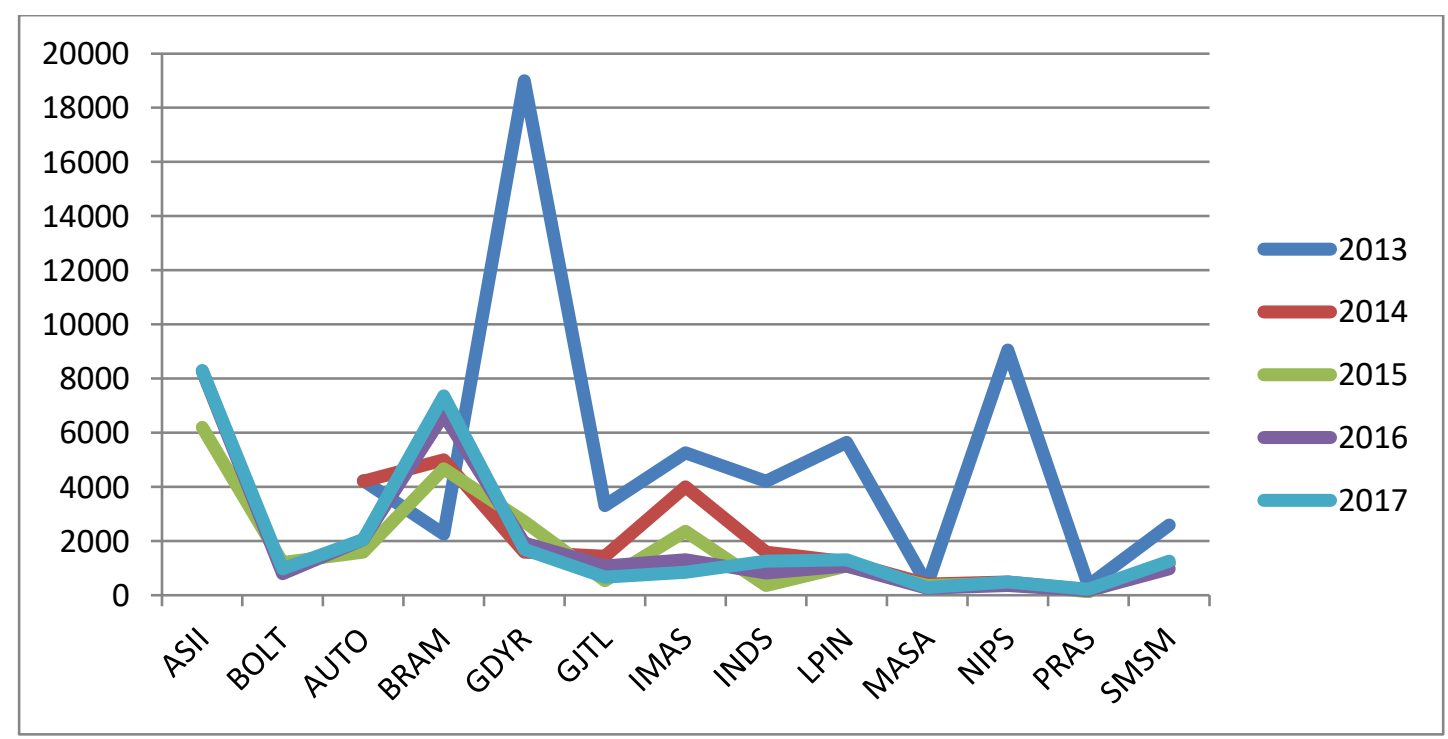

Data diolah, $2018^{9}$

Membaiknya kondisi perdagangan saham di Bursa Efek Indonesia (BEI) mampu menarik kembali para investor untuk meramaikan perdagangan saham bahkan mampu menarik masyarakat umum untuk menginvestasikan kelebihan dananya di pasar saham.10 Untuk mengetahui perkembangan saham yang semakin meningkat diperlukan Indeks harga saham sebagai cerminan dari pergerakan harga saham. Indeks harga saham merupakan trend

\footnotetext{
${ }^{7}$ Christine Dwi Karya Susilawati, Jurnal Riset dan Manajemen (Universitas Pendidikan Indonesia 2012, Vol. 4), hlm. 3

${ }^{8}$ https://tirto.id/membaca-saham-otomotif-dari-naik-turun-jualan-motor-mobil-cyou

${ }^{9}$ www.idx.co.id di akses pada 14 oktober 2018

${ }^{10}$ Erlin Yulia Rahma dkk, Analisis Variabel Fundamental yang Berpengaruh terhadap Price Earning Ratio (PER) sebagai Dasar Penilaian Saham pada Perusahaan Automotive and Allied yang Terdaftar di Bursa Efek Indonesia, (Jurnal Aplikasi Manajemen (JAM) Vol 12 No 3) 62
}

Shafin: Finance and Sharia Accounting Journal

Vol. 1 No. 1 Maret 2021 
pasar yang menggambarkan kondisi pasar suatu saat apakah pasar sedang lesu atau aktif. ${ }^{11}$ Saat ini, PT. Bursa Efek Indonesia (BEI) memiliki 11 jenis Indeks harga saham yang secara terus menerus disebarluaskan melalui media cetak maupun elektronik.

Indonesia memiliki dua Jenis Indeks Saham Syariah yaitu Indeks Saham Syariah Indonesia (ISSI) dan Jakarta Islamic Indeks (JII) di Bursa Efek Indonesia. Indeks saham syariah Indonesia (ISSI) memiliki 335 saham syariah yang tercantum dalam Daftar Efek Syariah (DES) dan Jakarta Islamic Indeks hanya terdiri dari 30 saham syariah.

Indeks Saham Syariah Indonesia merupakan indikator dari kinerja pasar saham syariah Indonesia. Konstituen ISSI adalah seluruh saham syariah yang tercatat di BEI dan masuk ke dalam Daftar Efek Syariah yang diterbitkan oleh OJK. Konstituen ISSI diseleksi ulang sebanyak dua kali dalam setahun, mengikuti jadwal review DES. Setiap periode seleksi selalu ada saham syariah yang keluar masuk menjadi konstituen Indeks Saham Syariah Indonesia. ${ }^{12}$

Umumnya tujuan investor menanamkan dananya untuk mendapatkan return (hasil) maksimal pada resiko minimal. Masyarakat mulai sadar bahwa berinvestasi di pasar saham jauh lebih menguntungkan dibandingkan dengan menyimpan dana di bank dalam bentuk deposito yang rata-rata hanya memberikan earning $6 \%$ pertahun. Informasi mengenai investasi saham dapat dilihat dari analisis laporan rasio keuangan suatu perusahaan. ${ }^{13}$

Kegiatan investasi adalah kegiatan untuk menanam modal pada satu asset atau lebih dengan harapan pada waktunya nanti pemilik modal memperoleh sejumlah keuntungan dari hasil penanaman modal tersebut, untuk memastikan keuntungan jangka panjang dan jangka pendek. ${ }^{14}$ Oleh sebab itu, Perlu melakukan analisis laporan keuangan secara sistematis dan terukur agar hasil yang diperoleh dapat dijadikan pendukung dalam pengambilan keputusan terutama keputusan jangka panjang. Investor bisa dengan cepat memperbaiki keputusan investasi jika mempelajari dan memperhatikan dengan teliti faktor-faktor yang mempengaruhi harga sekuritas. ${ }^{15}$

Untuk mengukur tingkat keberhasilan perusahaan dalam aktifitas investasi terdapat suatu analisis. ${ }^{16}$ Salah satu analisis rasio keuangan yang dapat digunakan untuk melakukan penilaian saham adalah pendekatan price earning ratio yaitu rasio antara harga pasar saham dengan laba per lembar saham. Pendekatan price earning ratio ini sering digunakan oleh analisis sekuritas untuk menilai harga saham karena pada dasarnya price earning ratio memberikan indikasi tentang jangka waktu yang diperlukan untuk

\footnotetext{
11 Nor Hadi, Pasar Modal (Acuan Teoritis dan Praktis Investasi di Instrumen Keuangan Pasar Modal), (Yogyakarta: Graha ilmu, 2013), hlm. 184

${ }^{12}$ Www.idx.co.id diakses pada 02 Desember 2018

${ }^{13}$ Desak Gede Sari Kusumadewi \& Gede Mertha Sudiartha, "Pengaruh Likuiditas, Dividend Payout Ratio, kesempatan Investasi dan Leverage terhadap Price Earning Ratio pada sektor industry barang konsumsi di Bursa Efek Indonesia periode 2010-2014”, (E-Jurnal Manajemen Unud, 2016), Vol. 5

${ }^{14}$ Latipah ratna sari, "Pengaruh NPM, ROE, EPS terhadap Return Saham pada perusahaan farmasi di BEI”.(Jurnal Ilmu dan Riset Mananjemen, 2016), Volume. 5

${ }^{15}$ Irham fahmi, Manajemen Keuangan Perusahaan (Jakarta:Mitra Wacana Media, 2004),hlm. 279

${ }^{16}$ Tammy Aryanti Putri Suparlan, "Pengaruh Return On Equity (ROE) dan Earning Per Share (EPS) terhadap Harga Saham (Studi kasus pada perusahaan Manufaktur sector Otomotif yang terdaftar di Bursa Efek Indonesia tahun period 2012-2014)"
} 
mengembalikan dana pada tingkat harga saham dan keuntungan perusahaan pada suatu periode tertentu. ${ }^{17}$

Price Earning Ratio (PER) merupakan ukuran yang paling banyak digunakan oleh investor untuk menentukan apakah investasi modal yang dilakukannya menguntungkan atau merugikan. ${ }^{18}$ Disamping itu PER juga dapat membantu para analis untuk memperbaiki judgement karena harga saham pada saat ini merupakan cermin prospek perusahaan di masa yang akan datang. Dibanding dengan metode arus kas, metode ini memiliki kelebihan antara lain karena memudahkan dan kepraktisan serta adanya standar yang memudahkan pemodal untuk melakukan perbandingan penilaian terhadap perusahaan yang lain di industri yang sama. ${ }^{19}$ Tentunya banyak faktor yang mempengaruhi tinggi rendahnya PER. Oleh karena itu, penelitian ini berupaya mempelajari pengaruh beberapa faktor yaitu Debt To Equity Ratio, Return on Equity, Earning Per Share

Debt to Equity Ratio untuk mengukur seberapa besar perusahaan dibiayai dengan utang.Semakin tinggi rasio ini menunjukkan semakin jelek, karena semakin tinggi pula resiko keuangan yang ditanggungoleh perusahaan. Hal ini disebabkan karena semakin besar proporsi dana yang berasal dari hutang atau dengan kata lain semakin besar rasio utang dengan aset berarti makin besar resiko keuangan perusahaan. ${ }^{20}$ Semakin tinggi rasio ini, semakin rendah pendanaan perusahaan yang disediakan oleh pemegang saham ${ }^{21}$.

Return On Equity merupakan rasio penting bagi para pemilik dan pemegang saham karena rasio tersebut menunjukkan kemampuan perusahaan dalam mengelola modal dari pemegang saham untuk mendapatkan laba bersih. Kenaikan Return On Equity biasanya akan diikuti oleh kenaikan harga saham perusahaan. Semakin tinggi ROE berarti semakin baik kinerja perusahaan dalam mengelola modalnya untuk menghasilkan keuntungan bagi pemegang saham. ${ }^{22}$

Earning Per share merupakan rasio untuk mengukur keberhasilan manajemen dalam mencapai keuntungan bagi pemegang saham. Rasio yang rendah berarti manajemen belum berhasil untuk memuaskan pemegang saham, sebaliknya dengan rasio yang tinggi, maka kesejahteraan pemegang saham meningkat dengan pengertian lain, bahwa tingkat pengembalian yang tinggi. ${ }^{23}$ Oleh karena itu, kinerja keuangan perusahaan akan berdampak terhadap kenaikan harga saham perusahaan.hal ini membuat investor menjadi tertarik untuk membeli saham perusahaan serta juga berdampak pada harga saham yang semakin meningkat. ${ }^{24}$

\footnotetext{
${ }^{17}$ Jurnal Analisis Price Earning Ratio Beserta Faktor-faktor yang Mempengaruhinya (Studi Empiris Pada Perusahaan Manufaktur yang Terdaftar di BEI Periode 2009-2012)

${ }^{18}$ Irham fahmi, Manajemen Keuangan Perusahaan.(Jakarta:Mitra Wacana Media, 2004),hlm. 84

${ }^{19}$ Puspa Damasita, "Pengaruh Faktor Leverage, Earning Growth, Dividen Payout Ratio, Size, dan Return On Equity Terhadap Price Earning Ratio pada Perusahaan Non-Keuangan yang Terdaftar di BEI Periode tahun 2006-2009", (jurnal Ekonomi Fakultas Ekonomi Universitas Diponegoro, 2011). Hal. 8

${ }^{20}$ Abdul Halim, Manajemen Keuangan Bisnis Konsep dan Aplikasi, (Jakarta: PT. Mitra wacana Media, 2015), hlm. 216

${ }^{21}$ Thomas Sumarsan, Sistem Pengendalian Manajemen, (Jakarta: PT Indeks, 2010), hlm. 54

${ }^{22}$ Tammy Aryanti Putri Suparlan, "Pengaruh Return On Equity (ROE) dan Earning Per Share (EPS) terhadap Harga Saham (Studi kasus pada perusahaan Manufaktur sector Otomotif yang terdaftar di Bursa Efek Indonesia tahun period 2012-2014)"

${ }^{23}$ Kasmir, Pengantar Majemen Keuangan, (Jakarta: Kencana, 2010), hlm. 115

${ }^{24}$ Ni Iluh Putu Wiagustini, dasar-dasar Manajemen Keuangan, (Denpasar: Udayana University Press, 2010), hlm. 81
}

64

Shafin: Finance and Sharia Accounting Journal

Vol. 1 No. 1 Maret 2021 
Pengaruh Debt To Equity Ratio, Return On Equity, Earning Per Share Terhadap Price Earning Ratio Pada Perusahaan Sektor Otomotif yang Terdaftar di Indeks Saham Syariah Indonesia (ISSI) Tahun 2013-

Dari uraian yang telah dikemukakan maka penelitimelakukan penelitian dengan judul “Pengaruh Debt To Equity Ratio, Return on Equity, Earning Per Share terhadap Price Earning Ratio pada Perusahaan Sektor Otomotif yang Terdaftar di Indeks Saham Syariah Indonesia (ISSI) Tahun 2013-2017"

Berdasarkan latar belakang yang telah diuraikan, makadapat dirumuskan masalah sebagai berikut:

1. Apakah Debt To Equity Ratio, Return on Equity, Earning Per Share secara Simultan (bersama-sama) berpengaruh terhadap Price Earning Ratio pada Perusahaan Sektor Otomotif yang terdaftar di Indeks Saham Syariah Indonesia (ISSI) Tahun 2013-2017?

2. Variabel manakah dari Debt To Equity Ratio, Return on Equity, Earning Per Share yang paling berpengaruh terhadap Price Earning Ratio pada Perusahaan Sektor Otomotif yang terdaftar di Indeks Saham Syariah Indonesia (ISSI) Tahun 2013-2017?

Pasar modal memiliki peran penting dalam mendorong perekonomian Negara, Pasar moda dapat dijadikan sebagai salah satu ukuran untuk melihat maju mundurnya bisnis suatu Negara. Pasar Modal merupakan tempat dimana berbagai pihak khususnya perusahaan menjual saham (stock) dan obligasi (bond) dengan tujuan dari hasil penjualan tersebut nantinya akan dipergunakan sebagai tambahan dana atau untuk memperkuat modal perusahaan..$^{25}$

Sebagai layaknya suatu pasar yang mempunyai sifat pelaku, pasar modal juga terdiri dari banyak pihak yang masing-masing memiliki peran sendiri.

a. Emiten.

b. Penjamin emisi.

c. Penanggung.

d. Profesi penunjang pasar modal mempunyai peran penting dalam penawaran umum.

e. Investor. ${ }^{26}$

Analisis harga saham umumnya dapat dilakukan oleh para investor di pasar modal dengan mengamati dua pendekatan dasar, yaitu:

a. Analisis Teknikal

b. Analisis Fundamental

\section{Kinerja perusahaan}

Kinerja perusahaan merupakan penilaian terhadap efisiensi dan produktifitas perusahaan yang dilakukan secara berkala atas laporan manajemen dan laporan keuangan. Hasil penilaian kinerja dapat digunakan untuk menentukan penggolongan tingkat kesehatan keuangan perusahaan. Untuk mengukur kinerja suatu perusahaan perlu ditentukan aspek yang menjadi tolak ukur mengukur kinerja. Tolak ukur tersebut penting untuk menentukan pencapaian kinerja perusahaan secara empiris, sehingga informasi yang diberikan dapat mencerminkan kinerja perusahaan dalam kurun waktu tertentu. ${ }^{27}$

Analisis rasio keuangan adalah perhitungan rasio-rasio untuk menilai keadaan keuangan perusahaan dimasa lalu, saat ini dan kemungkinannya dimasa yang akan datang". 28

\footnotetext{
${ }^{25}$ Irham fahmi, Manajemen Keuangan Perusahaan.(Jakarta:Mitra Wacana Media, 2004),hlm. 305

${ }^{26}$ Tavinayati, Yulia Qamariyanti, Hukum Pasar Modal Indonesia, (Jakarta: Sinar Grafika, 2013), Hlm. 23

${ }^{27}$ Ibid, 64

${ }^{28}$ Puspa Damasita, "Pengaruh Faktor Leverage, Earning Growth, Dividen Payout Ratio, Size, dan Return On Equity Terhadap Price Earning Ratio pada Perusahaan Non-Keuangan yang Terdaftar di BEI Periode tahun 2006-2009”, (jurnal Ekonomi Fakultas Ekonomi Universitas Diponegoro, 2011). Hal. 37
} 
Dari hasil analisis rasio keuangan akan diketahui kondisi kinerja perusahaan yang bersangkutan.

1. Rasio Solvabilitas/kebijakan keuangan pasar

2. Rasio Profitabilitas

3. Rasio Nilai Pasar (Market value rations)

\section{Perusahaan sektor otomotif}

Industri otomotif merupakan perusahaan go public yang menjadi salah satu sektor andalan yang terus diprioritaskan pengembangannya karena berperan besar terhadap pertumbuhan ekonomi nasional. Apalagi Indonesia masih menjadi negara tujuan utama untuk investasi di sektor otomotif. ${ }^{29}$

Produksi otomotif dunia yang terus berkembang dalam memenuhi kebutuhan konsumen, Indonesia termasuk salah satu pasar otomotif paling potensial di dunia. Penjualan mobil di Indonesia pada 2013 mencapai 1,22 juta unit meningkat 10\% dari tahun sebelumnya sebanyak 1,12 juta. Produksi mobil di Indonesia, selain untuk dijual dipasar domestik, para produsen otomotif juga mengekspor mobil dan motor dengan jumlah yang besar. Angka produksi dan penjualan kendaraan bermotor dunia tentunya menjadi cerminan potensi pasar ekspor suku cadang, aksesoris dan perlengkapan mobil dan motor. ${ }^{30}$.

\section{METODE PENELITIAN}

\section{Rancangan Penelitian}

Penelitian ini menggunakan pendekatan kuantitatif yaitu penelitian dengan menggunakan angka-angka dan metode yang digunakan adalah Explanatory. Metode Explanatory yang digunakan termasuk dalam hubungan kausal. Hubungan kausal merupakan hubungan sebab akibat. ${ }^{31}$ Analisis penelitian menggunakan regresi linear berganda yaitu untuk mengetahui adakah pengaruh Debt To Equity Ratio, Return On Equity, Earning Per Share terhadap Price Earning Ratio Pada perusahaan Otomotif yang terdaftar di Indeks Saham Syariah Indonesia (ISSI). Variabel dalam penelitian ini adalah variabel X (independent variable) adalah Debt To Equity Ratio, Return On Equity, Earning Per Share, Sedangkan variabel Y (dependent variable) adalah Price Earning Rati.

Gambar 1

Desain Penelitian

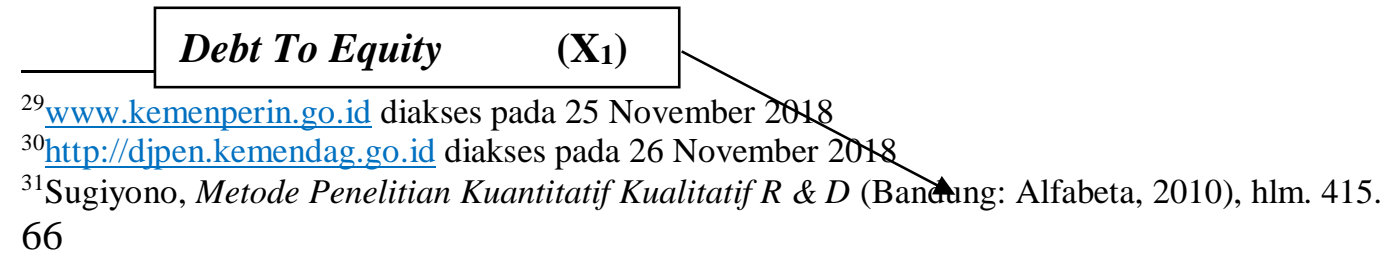

Shafin: Finance and Sharia Accounting Journal

Vol. 1 No. 1 Maret 2021 
Pengaruh Debt To Equity Ratio, Return On Equity, Earning Per Share Terhadap Price Earning Ratio Pada Perusahaan Sektor Otomotif yang Terdaftar di Indeks Saham Syariah Indonesia (ISSI) Tahun 2013-

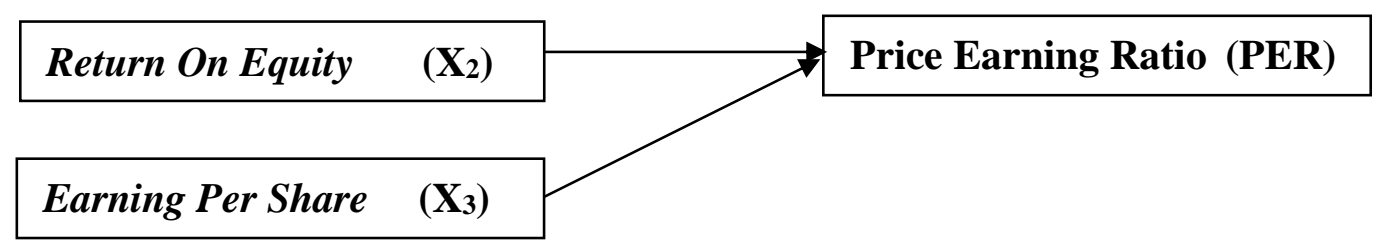

Data Penelitian, 2019

\section{Populasi dan sampel}

Populasi merupakan wilayah generalisasi yang terdiri atas obyek/subyek yang mempunyai kualitas dan karakteristik tertentu yang ditetapkan oleh peneliti untuk dipelajari dan kemudian ditarik kesimpulan. ${ }^{32}$ Populasi yang menjadi objek dalam penelitian ini adalah perusahaan sektor otomotif yang terdaftar di Indeks Saham Syariah Indonesia pada tahun 2013-2017.

\section{Instrument penelitian}

Instrumen penelitian adalah suatu alat yang digunakan untuk mengukur fenomena alam maupun sosial yang diamati (variabel penelitian). ${ }^{33}$ Adapun instrumen yang digunakan dalam penelitian ini adalah dokumentasi berupa data laporan keuangan publikasi IDX.com, Jenis data yang dipakai adalah data sekunder. Data sekunder adalah data yang diperoleh dalam bentuk jadi dan telah diolah oleh pihak lain, dikumpulkan dan disatukan oleh studi-studi sebelumnya, yang biasanya dalam bentuk publikasi ${ }^{34}$. Peneliti memakai data sekunder yang berupa data-data laporan keuangan yang telah di sediakan secara lengkap dan akurat di www.idx.co.id.

\section{Pengumpulan Data}

Langkah-langkah yang diambil dalam pengumpulan data yang berkaitan dengan penulisan Penelitian ini adalah sebagai berikut :

1) Studi Pustaka

2) Dokumentasi

\section{Analisis data}

Untuk mencapai tujuan penelitian digunakan analisis regresi berganda.Analisis regresi ini dapat digunakan untuk memperoleh gambaran yang menyeluruh mengenai hubungan antara variabel dependen dan independen secara menyeluruh baik secara simultan atau secara parsial. Sebelum melakukan uji regresi linier berganda, metode mensyaratkan untuk melakukan uji asumsi klasik guna mendapatkan hasil yang terbaik. ${ }^{35}$ Dalam pelaksanaan perhitungan ini peneliti menggunakan alat bantu IBM SPSS Statistik versi 20

1) Statistik Deskriptif Penelitian

2) Uji Asumsi Klasik

\footnotetext{
32 Sugiyono, Metode Penelitian Bisnis, (Bandung: Alfabeta, 2012), hlm.115

${ }^{33}$ Sugiyono, Metode Penelitian Bisnis, (Bandung: Alfabeta, 2012), hlm. 146

${ }^{34}$ Ibid

${ }^{35}$ Imam Ghozali, Aplikasi Analisis Multivariate Dengan Program IBM SPSS 19 (Semarang: Universitas Diponegoro, 2011), hlm. 97
} 


\section{Pengujian Hipotesis}

Untuk melakukan pengujian terhadap hipotesis-hipotesis yang diajukan, perlu digunakan analisi regresi melalui uji t maupun uji f. Tujuan digunakan analisis regresi adalah untuk mengetahui pengaruh variabel-variabel independen terhadap variabel dependen, baik secara parsial maupun secara simultan, serta mengetahui besarnya dominasi variabel-variabel independen terhadap variabel dependen. Metode pengujian terhadap hipotesa yang diajukan dilakukan dengan pengujian secara parsial dan pengujian secara simultan

\section{HASIL DAN PEMBAHASAN \\ Gambaran Umum Objek Penelitian}

Objek penelitian yang dilakukan oleh peneliti adalah perusahaan yang terdaftar di Indeks Saham Syariah Indonesia (ISSI) dengan menganalisis data laporan keuangan tahunan perusahaan pada periode 2013-2017. Perusahaan yang dimaksud adalah perusahaan Otomotif yang terdaftar di Indeks Saham Syariah Indonesia (ISSI) periode 2013-2017.

Indeks Saham Syariah Indonesia (ISSI) merupakan indikator dari kinerja pasar saham syariah Indonesia. Konstituen ISSI adalah seluruh saham syariah yang tercatat di BEI dan masuk ke dalam Daftar Efek Syariah yang diterbitkan oleh OJK. Konstituen ISSI diseleksi ulang sebanyak dua kali dalam setahun, mengikuti jadwal review DES. Setiap periode seleksi selalu ada saham syariah yang keluar masuk menjadi konstituen Indeks Saham Syariah Indonesia. ${ }^{36}$

Berikut ini adalah gambaran umum perusahaan yangmenjadi objek penelitian iniyaitu Perusahaan manufaktur yang terdaftar pada Indeks Saham Syariah Indonesia (ISSI) khususnya pada sektor Otomotif dari tahun 2013-2017 dari 12 perusahaan yang sudah memenuhi criteria pengambilan sampel terdapat 35 sampel, antara lain:

\section{a. $\quad$ PT Astra International Tbk (ASII)}

PT Astra International Tbk didirikan di Jakarta pada 20 Februar 1957 sebagai sebuah perusahaan perdagangan umum dengan nama Astra International Inc. dengan mencakup 7 bidang Usaha perdagangan umum, perindustrian, pertambangan, pengangkutan, pertanian, pembangunan, jasa dan konsultasi Seiring dengan kemajuan usaha serta sejalan dengan rencana ekspansi, Perseroan melakukan penawaran umum perdana di Bursa Efek Indonesia dengan menggunakan kode saham ASII pada tahun 1990, sekaligus mengubah namanya menjadi PT Astra International Tbk. Modal dasar Rp3.000.000.000.000, terdiri dari 60.000.000.000 lembar saham dengan nominal Rp50 per saham, Astra memiliki 229 anak perusahaan, diantaranta: PT. Arya Kharisma , PT. Astra Agro Lestari Tbk and subsidiaries, PT. Astra Auto Trust, PT. Astra Autoprima, PT. Astra Multi Finance dll. ${ }^{37}$

\section{b. $\quad$ PT Astra Otoparts Tbk(AUTO)}

PT Astra Otoparts Tbk (Astra Otoparts) merupakan grup perusahaan komponen otomotif terbesar di Indonesia. Perseroan di dirikan pertama kali dengan nama PT Alfa Delta Motor pada tahun 1976. Pada tahun 1977 Perseroan berubah nama menjadi PT Pacific Western, yang namanya berubah menjadi PT Menara Alam Teknik di tahun 1991 Pada 4 Desember 1997, nama Perseroan kemudian diubah menjadi PT Astra Otoparts. Berdasarkan Anggaran

\footnotetext{
${ }^{36}$ www.idx.co.id diakses pada 22 April 2019

${ }^{37}$ Laporan Tahunan Annual Report 2017, hlm. 62
}

68

Shafin: Finance and Sharia Accounting Journal

Vol. 1 No. 1 Maret 2021 
Dasar Perusahaan, ruang lingkup kegiatan AUTO terutama bergerak dalam perdagangan suku cadang kendaraan bermotor, baik lokal maupun ekspor, dan manufaktur dalam bidang industri logam, plastik dan suku cadang kendaraan bermotor. Pada tanggal 29 Mei 1998, AUTO memperoleh pernyataan efektif dari Bapepam-LK untuk melakukan Penawaran Umum Perdana Saham AUTO (IPO) kepada masyarakat sebanyak 75.000.000 saham dengan nilai nominal Rp500,- per saham dan harga perdana sebesar Rp575,- per saham. Pada tanggal 15 Juni 1998, saham tersebut telah dicatatkan pada Bursa Efek Indonesia. Astra Otopart memiliki 56 anak perusahaan diantaranya: PT. Astra Komponen Indonesia, PT. Autoplastik Indonesia, PT. Century Batteries Indonesia, PT. FSCM Manufacturing Indonesia, PT. Indokarlo Perkasa $^{38}$

\section{c. $\quad$ PT Indo Kordsa Tbk (BRAM)}

Perseroan didirikan pada tahun 1981 dengan nama PT Branta Mulia sebagai perusahaan pemasok utama bahan penguat ban premium di kawasan Asia Tenggara. Perseroan bidang usaha bergerak dalam industri kain ban, serat/fiament buatan, benang Nylon dan benang Polyester.Pada tanggal 20 Juli 1990, BRAM memperoleh izin Menteri Keuangan untuk melakukan Penawaran Umum Perdana Saham BRAM (IPO) kepada masyarakat sebanyak 12.500.000 dengan nilai nominal Rp1.000,- per saham dengan harga penawaran Rp9.250,per saham. Saham-saham tersebut dicatatkan pada Bursa Efek Indonesia (BEI) pada tanggal 05 September 1990. PT. Indo Kordsa memiliki anak perusahaan diantaranya: PT. Indo Kordsa Polyester dan Thai Indo Kordsa Co Ltd. ${ }^{39}$

\section{d. $\quad$ PT Goodyear Indonesia Tbk(GDYR)}

Goodyear Indonesia Tbk didirikan tanggal 26 Januari 1917 dengan namaNV The Goodyear Tire \& Rubber Company Limited dan memulai kegiatan usaha komersialnya pada tahun 1917. Berdasarkan Anggaran Dasar Perusahaan, ruang lingkup kegiatan GDYR adalah bergerak di bidang industri ban untuk kendaraan bermotor, pesawat terbang serta komponen lainnya yang terkait, juga penyaluran dan ekspor ban. Pada tahun 1980, GDYR memperoleh pernyataan efektif dari BAPEPAM-LK untuk melakukan Penawaran Umum Perdana Saham GDYR (IPO) kepada masyarakat sebanyak 6.150.000 dengan nilai nominal Rp1.000,- per saham dengan harga penawaran Rp1.250,- per saham. Saham-saham tersebut dicatatkan pada Bursa Efek Indonesia (BEI) pada tanggal 22 Desember 1980. ${ }^{40}$

\section{e. Indospring Tbk (INDS)}

Indospring Tbk didirikan tanggal 05 Mei 1978 dan memulai kegiatan usaha komersialnya pada tahun 1979, Induk usaha utama Indospring adalah PT Indoprima Investama. Berdasarkan Anggaran Dasar Perusahaan, ruang lingkup kegiatan INDS bergerak dalam bidang industri spare parts kendaraan bermotor khususnya pegas, yang berupa leaf spring (pegas daun), coil spring (pegas spiral) memiliki 2 produk turunan yaitu hot coil spring dan cold coil spring, valve spring (pegas katup) dan wire ring. Pada tanggal 26 Juni 1990, INDS memperoleh pernyataan efektif dari Bapepam-LK untuk melakukan Penawaran Umum Perdana Saham INDS (IPO) kepada masyarakat sebanyak 3.000.000 dengan nilai nominal

\footnotetext{
${ }^{38}$ Ibid, 54

${ }^{39} \mathrm{Ibid}, \mathrm{hlm} .28$

${ }^{40}$ Ibid, hlm. 25
} 
Rp1.000,- per saham dengan harga penawaran Rp9.000,- per saham. Saham-saham tersebut dicatatkan pada Bursa Efek Indonesia (BEI) pada tanggal 10 Agustus 1990.

f. PT Selamat Sempurna Tbk (SMSM)

Selamat Sempurna Tbk didirikan di Indonesia pada tanggal 19 Januari 1976 dan memulai kegiatan operasi komersialnya sejak tahun 1980.Berdasarkan Anggaran Dasar Perusahaan, ruang lingkup kegiatan SMSM terutama adalah bergerak dalam bidang industri alat-alat perlengkapan (suku cadang) dari berbagai macam alat-alat mesin pabrik dan kendaraan, dan yang sejenisnya. Merek produk dari Selamat Sempurna Tbk, antara lain: merek Sakura untuk produk S/F dan Filtration; dan merek ADR untuk produk radiator, dump hoist, coolant dan brake parts.Pada tanggal 13 Agustus 1996, SMSM memperoleh pernyataan efektif dari BAPEPAM-LK untuk melakukan Penawaran Umum Perdana Saham SMSM (IPO) kepada masyarakat sebanyak 34.400.000 saham dengan nilai nominal Rp500,- per saham dan harga penawaran Rp1.700,- per saham. Saham-saham tersebut dicatatkan pada Bursa Efek Indonesia (BEI) pada tanggal 09 September 1996. ${ }^{41}$

g. $\quad$ Prima Alloy Stell Universal Tbk(PRAS)

Prima Alloy Steel Universal Tbk didirikan tanggal 20 Februari 1984 dan memulai kegiatan usaha komersialnya pada tahun 1986. Berdasarkan Anggaran Dasar Perusahaan, ruang lingkup kegiatan PRAS meliputi industri rim, stabilizer, velg aluminium dan peralatan lain dari alloy aluminium dan baja, serta perdagangan umum untuk produk-produk tersebut. Saat ini, Prima Alloy Steel bergerak dalam bidang industri velg kendaraan bermotor roda empat (dengan merek dagang Panther, PCW, Devino, Akuza, Incubus, Ballistic, Menzari, dan Viscera) yang terbuat dari bahan aluminium alloy yang umumnya dikenal sebagai velg racing atau aluminium alloy wheels. Pada tahun 1990, PRAS memperoleh pernyataan efektif dari Bapepam-LK untuk melakukan Penawaran Umum Perdana Saham PRAS (IPO) kepada masyarakat sebanyak 2.000.000 dengan nilai nominal Rp1.000,- per saham dengan harga penawaran Rp6.750,- per saham. Saham-saham tersebut dicatatkan pada Bursa Efek Indonesia (BEI) pada tanggal 12 Juli 1990.42

\section{A. Pembuktian Hipotesis}

Hipotesis dalam penelitian dengan judul "Pengaruh Debt To Equity Ratio, Return On Equity, Earning Per Share Terhadap Price Earning Ratio pada Perusahaan Sektor Otomotif yang Terdaftar di Indeks Saham Syariah Indonesia (ISSI) Tahun 2013-2017" adalah sebagai berikut:

Diduga X1 (Debt To Equity Ratio), X2 (Return On Equity), X3 (Earning Per Share) secara Simultan (bersama-sama) berpengaruh terhadap Y (Price Earning Ratio) pada Perusahaan Sektor Otomotif yang Terdaftar di Indeks Saham Syariah Indonesia (ISSI) Tahun 20132017 ?

Diduga antara X1 (Debt To Equity Ratio), X2 (Return On Equity), X3 (Earning Per Share) variabel yang paling berpengaruh terhadap Price Earning Ratio pada Perusahaan Sektor Otomotif yang terdaftar di Indeks Saham Syariah Indonesia (ISSI) Tahun 2013-2017.

Selanjutnya untuk membuktikan hipotesis tersebut dilakukan beberapa pengujian sebagai berikut:

\footnotetext{
${ }^{41}$ Ibid, hlm. 13

${ }^{42}$ Ibid, hlm. 16

70
}

Shafin: Finance and Sharia Accounting Journal

Vol. 1 No. 1 Maret 2021 
Pengaruh Debt To Equity Ratio, Return On Equity, Earning Per Share Terhadap Price Earning Ratio Pada Perusahaan Sektor Otomotif yang Terdaftar di Indeks Saham Syariah Indonesia (ISSI) Tahun 2013-

\section{a. Analisis Regresi Linier Berganda}

Penelitian ini model regresi linier berganda yang disusun untuk mengetahui implikasi variable bebas terhadap variable terikat pada perusahaan otomotif dalam Indeks Saham Syariah Indonesia tahun 2013-2017 adalah: $Y=a+b 1 X 1+b 2 X 2+b 3 X 3$ Analisis menggunakan program SPSS versi, diperoleh hasil sebagai berikut:

Tabel 1

Hasil Analisis Regresi Linier Berganda

\begin{tabular}{|c|c|c|c|c|c|c|c|c|}
\hline \multirow[t]{2}{*}{ Model } & & \multicolumn{2}{|c|}{$\begin{array}{l}\text { Unstandardized } \\
\text { Coefficients }\end{array}$} & \multirow{2}{*}{$\begin{array}{c}\begin{array}{c}\text { Standardize } \\
\text { d } \\
\text { Coefficients }\end{array} \\
\text { Beta }\end{array}$} & \multirow[t]{2}{*}{$\mathrm{t}$} & \multirow[t]{2}{*}{ Sig. } & \multicolumn{2}{|c|}{$\begin{array}{l}\text { Collinearity } \\
\text { Statistics }\end{array}$} \\
\hline & & B & $\begin{array}{l}\text { Std. } \\
\text { Error }\end{array}$ & & & & $\begin{array}{c}\text { Toleranc } \\
\mathrm{e}\end{array}$ & VIF \\
\hline \multirow{4}{*}{1} & (Constant) & 50.189 & 18.210 & & 2.756 & .010 & & \\
\hline & $\begin{array}{l}\text { Debt To Equity } \\
\text { Ratio }\end{array}$ & 43.057 & 20.628 & .362 & 2.087 & .045 & .940 & 1.064 \\
\hline & $\begin{array}{l}\text { Return On } \\
\text { Equity }\end{array}$ & -.427 & .748 & -.104 & -.571 & .572 & .850 & 1.177 \\
\hline & $\begin{array}{l}\text { Earning Per } \\
\text { Share }\end{array}$ & .003 & .027 & .022 & .125 & .901 & .875 & 1.143 \\
\hline
\end{tabular}

a. Dependent Variable: Price Earning Ratio

Sumber: Output SPSS versi 20 data diolah (2019)

Analisis regresi linier berganda pada tabel diatas diperoleh koefisien variabel DER $=43,057$ $(X 1)$, Variabel ROE $=-0,427(X 2)$ dan EPS $=-0.003(X 3)$ serta konstanta (a) sebesar 50.189 , sehingga model persamaan regresi linier berganda yang diperoleh dalam penelitian ini adalah sebagai berikut:

$\mathrm{Y}=50,189+(0,362)(43,057)+(-0,104)(-0.427)+(0,022)(0.003)$

Model persamaan regresi linear diatas dapat diinterpretasikan sebagai berikut:

a. $\quad \mathrm{a}=50,189$, dimana nilai konstanta profitabilitas sebesar 50,189 menunjukkan bahwa apabila nilai variabel independen bernilai tetap/konstan maka nilai variable Price Earning Ratio sebesar 50,189.

b. Variable DER $=43,057$, dapat diartikan bahwa besarnya koefisien variabel DER bertanda positif $(43,057)$ mengindikasikan bahwa adanya penurunan DER, maka akan terjadi kenaikan pada PER sebesar 43,057.

c. Variable $\mathrm{ROE}=0,0427$, dapat diartikan bahwa besarnya koefisien variabel ROE bertanda negatif $(-0,427)$ mengindikasikan bahwa adanya penurunan ROE, maka akan terjadi penurunan pada PER sebesar -0,427.

d. Variable EPS $=0.003$, dapat diartikan bahwa besarnya koefisien variabel EPS bertanda positif (0.003) mengindikasikan bahwa adanya kenaikan EPS, maka akan terjadi kenaikan pada PER sebesar 0.003.

e. Sandart Error sebesar 18,210 artinya seluruh variabel yang dihitung dalam uji SPSS memiliki tingkat variabel pengganggu sebesar 18,210. 


\section{b. Uji F (Simultan)}

Uji statistik F digunakan untuk mengetahui apakah semua variabel independen atau bebas yang dimasukkan mempunyai pengaruh secara bersama-sama terhadap variabel dependen/terikat. Adapaun cara pengujian dalam uji $\mathrm{f}$ ini yaitu dengan tabel ANOVA (Analysis of Variance) dengan melihat nilai $\mathrm{f}_{\text {hitung }}$ pada tabel ANOVA yang kemudian dibandingkan dengan $\mathrm{f}_{\text {tabel }}(a(\mathrm{~m}-1, \mathrm{n}-\mathrm{m}))$. Jika $\mathrm{f}_{\text {hitung }}>\mathrm{f}_{\text {tabel }}(a(\mathrm{~m}-1, \mathrm{n}-\mathrm{m}))$ maka dapat disimpulkan bahwa variabel bebas (DER, ROE dan EPS) secara bersama-sama berpengaruh terhadap variabel terikat (Price Earning Ratio). Berikut adalah tabel ANOVA pada tabel

Tabel 2

Hasil Uji F

\begin{tabular}{llrrrrr}
\hline Model & & $\begin{array}{c}\text { Sum of } \\
\text { Squares }\end{array}$ & df & Mean Square & F & Sig. \\
\hline \multirow{2}{*}{1} & Regression & 3.696 & 3 & 1.232 & 3.083 & $.043^{\mathrm{b}}$ \\
\cline { 2 - 8 } & Residual & 11.191 & 28 & .400 & & \\
\cline { 2 - 7 } & Total & 14.888 & 31 & & & \\
\hline
\end{tabular}

a. Dependent Variable: PER

b. Predictors: (Constant), EPS, DER, ROE

Sumber: Output SPSS versi 20 data diolah (2019)

Berdasarkan tabel 4.10 di atas maka diperoleh nilai $\mathrm{F}_{\text {hitung }}=3$,083dengan tingkat signifikan 0,043. Sedangkan untuk menentukan nilai $\mathrm{F}_{\text {tabel }} a=5 \%$ yaitu dv 1 (N1) dan dv $2(\mathrm{~N} 2)$ dapat ditentukan dengan persamaan $F_{\text {tabel }}\left(d_{1}(m-1)\right)$ dan $\left(d_{2} v_{2}(n-m)\right)$, dimana $m$ adalah jumlah variabel (variabel bebas $=$ variabel terikat) dan $\mathrm{n}$ adalah jumlah observasi $/$ sampel pembentuk regresi, jumlah sampel pembentuk regresi sebanyak 35 . Maka $d_{1}=m-1=4-1=3$ sedangkan $\mathrm{dv}_{2}=\mathrm{n}-\mathrm{m}=35-3=32$, jadi dapat dilihat pada tabel $\mathrm{F}$ pada baris 3 kolom 33 yaitu $F_{\text {tabel }}=2,90$. Dapat disimpulkan bahwa nilai $F_{\text {hitung }}>F_{\text {tabel }}(3,083>2,90)$, artinya semua variabel independen (DER, ROE dan EPS) secara bersama-sama berpengaruh positif signifikan terhadap variabel dependen Price Earning ratio.

\section{c. Koefisien Determinasi (Uji $\mathbf{R}^{2}$ )}

Koefisien determinasi $\left(\mathrm{R}^{2}\right)$ berfungsi untuk mengetahui sejauh mana atau seberapa besar kemampuan variable bebas (DER, ROE, dan EPS) terhadap varabel terikat (PER), hasil koefisien determinasi $\left(\mathrm{R}^{2}\right)$ dengan menggunakan SPSS 20 hasilnya adalah:

Tabel 3

Hasil Uji R ${ }^{2}$

\begin{tabular}{lrrrrr}
\hline Model & $\mathrm{R}$ & R Square & $\begin{array}{c}\text { Adjusted R } \\
\text { Square }\end{array}$ & $\begin{array}{c}\text { Std. Error of the } \\
\text { Estimate }\end{array}$ & Durbin-Watson \\
\hline 1 & $.498^{\mathrm{a}}$ & .248 & .168 & .63221 & 1.778 \\
\hline
\end{tabular}

a. Predictors: (Constant), EPS, DER, ROE

b. Dependent Variable: PER

Sumber: Outpus SPSS versi 20 data diolah (2019)

Analisis data diatas dapat diketahui bahwa besarnya $R$ Square adalah 0,248 atau 
Pengaruh Debt To Equity Ratio, Return On Equity, Earning Per Share Terhadap Price Earning Ratio Pada Perusahaan Sektor Otomotif yang Terdaftar di Indeks Saham Syariah Indonesia (ISSI) Tahun 2013-

24,8\%. Hal ini menjukkan bahwa variable independen X1 (Debt To Equity Ratio), X2 (Return On Equity), X3 (Earning Per Share)memberikan kontribusi terhadap Price Earning Ratio sebesar $24,8 \%$ sedangkan sisanya $75,2 \%$ dipengaruhi variable lain yang tidak dijelaskan dalam penelitian ini.

\section{Koefisien Korelasi}

Uji koefisien korelasi dilakukan untuk mengetahui adakah pengaruh secara parsial variable bebas $(\mathrm{X})$ terhadap variable terikat $(\mathrm{Y})$, sedangkan mencari koefisien korelasi dilakukan untuk mengetahui seberapa besar hubungan antara variable bebas (X) dan variable terikat (Y) dengan menggunakan SPSS 20. Adapun hasil uji koefisien sebagai berikut:

Tabel 4

Hasil Uji Koefisien Korelasi

\begin{tabular}{lrrrrr}
\hline Model & R & R Square & $\begin{array}{c}\text { Adjusted R } \\
\text { Square }\end{array}$ & $\begin{array}{c}\text { Std. Error of } \\
\text { the Estimate }\end{array}$ & $\begin{array}{l}\text { Durbin- } \\
\text { Watson }\end{array}$ \\
\hline 1 & $.498^{\mathrm{a}}$ & .248 & .168 & .63221 & 1.778 \\
\hline
\end{tabular}

a. Predictors: (Constant), EPS, DER, ROE

b. Dependent Variable: PER

Sumber: Outpus SPSS versi 20 data diolah (2019)

Tabel diatas menunjukkan bahwa pada kolom $\mathrm{R}$ adalah 0,498.Dengan demikian, besarnya koefisien Korelasi (r) adalah 0.498. jadi antara variable bebas X1 (Debt To Equity Ratio), X2 (Return On Equity), X3 (Earning Per Share) dan variable terikat Price Earni Ratio keeratan hubungannya adalah rendah, dikarenakan nilai koefisien korelasi adalah 0.498 atau sekitar $49,8 \%$.

\section{Uji t (Uji Parsial/Individual)}

Pengujian hipotesis yang dilakukan secara parsial bertujuan untuk mengetahui pengaruh dan signifikansi masing-masng variabel indepanden terhadap variabel dependen.Pengujian secara parsial menggunakan distribusi t yaitu membandingkan antara $t_{\text {hitung }}$ dengan $t_{\text {tabel }}$ dan dengan menggunakan probabilitas $0,005(a=0,5 \%)$ yaitu membandingkan nilai $a$ dengan nilai sig. pada tabel Coefficients. Jika $t_{h i t u n g}>t_{\text {tabel }}$ maka dapat disimpulkan bahwa variabel bebas tersebut berpengaruh secara signifikan terhadap variabel terikat.Sebalikny jika $t_{\text {hitung }}<t_{\text {tabel }}$ dikatakan tidak signifikan.Jika sig. $<a$ maka variabel bebas tersebut berpengaruh terhadap variabel terikat. Berikut adalah tabel Coefficient pada tabel berikut.Uji-t dilakukan untuk mengetahui adakah pengaruh antara variabel X1 (Debt To Equity Ratio), X2 (Return On Equity), X3 (Earning Per Share) dengan variabel Y (Price Earning Ratio) dengan a = 0,05. berikut hasil Uji-t dengan menggunakan SPSS versi 20.

Tabel 5

Hasil Uji t

\begin{tabular}{|c|c|c|c|c|c|c|}
\hline \multirow[t]{2}{*}{ Model } & $\begin{array}{r}\text { Unst } \\
\text { Co }\end{array}$ & $\begin{array}{l}\text { rdized } \\
\text { ents }\end{array}$ & \multirow{2}{*}{$\begin{array}{c}\text { Standardize } \\
\text { d } \\
\text { Coefficients } \\
\end{array}$} & \multirow[t]{2}{*}{$\mathrm{t}$} & \multirow[t]{2}{*}{ Sig. } & $\begin{array}{l}\text { Collinearity } \\
\text { Statistics }\end{array}$ \\
\hline & B & $\begin{array}{l}\text { Std. } \\
\text { Error }\end{array}$ & & & & $\begin{array}{cc}\begin{array}{c}\text { Toleranc } \\
\mathrm{e}\end{array} & \text { VIF } \\
\end{array}$ \\
\hline
\end{tabular}


Lailatul Musyarrofah dan Lely Shofa Imama

\begin{tabular}{|c|c|c|c|c|c|c|c|c|}
\hline \multirow{4}{*}{1} & (Constant) & 50.189 & 18.210 & & 2.756 & .010 & & \\
\hline & $\begin{array}{l}\text { Debt To Equity } \\
\text { Ratio }\end{array}$ & 43.057 & 20.628 & .362 & 2.087 & .045 & .940 & 1.064 \\
\hline & $\begin{array}{l}\text { Return On } \\
\text { Equity }\end{array}$ & -.427 & .748 & -.104 & -.571 & .572 & .850 & 1.177 \\
\hline & $\begin{array}{l}\text { Earning Per } \\
\text { Share }\end{array}$ & .003 & .027 & .022 & .125 & .901 & .875 & 1.143 \\
\hline
\end{tabular}

a. Dependent Variable: Price Earning Ratio

Sumber: Output SPSS versi 20 data diolah (2019)

\section{a) Uji t Variabel Debt To Equity Ratio (DER)}

Hasil perhitungan yang didapat pada tabel 4.11 variabel Debt To Equity Ratio (DER) secara statistik menunjukkan hasil Sig. 0,45 lebih besar dari $a(0,045>0,005)$. Nilai thitung sebesar 2,087, sedangkan untuk dapat mengetahui besarnya tabel yaitu dengan melihat $a=0,005$, dalam pengujian hipotesis untuk model regresi, derajat bebas ditentukan dengan rumus $n-2$. Dimana $n=$ banyak observasi, jadi $n-2=35-$ $2=33$ sehingga dapat diperoleh tabelnya sebesar 2,034 , artinya $t_{h i t u n g}<t_{\text {tabel }}(2,087>$ 2,034), sehingga $\mathrm{H}_{0}$ ditolakdan $\mathrm{H}_{a}$ diterima dan dapat disimpulkan bahwa variabel Debt To Equity Ratio (DER) secara parsial berpengaruh signifikan terhadap Price Earning Rasio.

\section{b) Uji t Variabel Return On Equity (ROE)}

Hasil perhitungan yang didapat pada tabel 4.11 variabel Return On Equity (ROE) secara statistik menunjukkan hasil Sig. 0,572 lebih besar dari $a(0,572>0,005)$. Nilai thitung sebesar -0,571, sedangkan untuk dapat mengetahui besarnya tabel yaitu dengan melihat $a=0,005$, dalam pengujian hipotesis untuk model regresi, derajat bebas ditentukan dengan rumus $n-2$. Dimana $n=$ banyak observasi, jadi $n-2=35-$ $2=33$ sehingga dapat diperoleh tabelnya sebesar 2,034, artinya $t_{\text {hitung }}<t_{\text {tabel }}(-$ $0,571<2,034)$ sehingga $\mathrm{H}_{0}$ diterima dan $\mathrm{H}_{\mathrm{a}}$ ditolak dan dapat disimpulkan bahwa variabel Return On Equity (ROE) secara parsial tidak berpengaruh signifikan terhadap Price Earning Rasio.

\section{c) Uji t Variabel Erning Per Share (EPS)}

Hasil perhitungan yang didapat pada tabel 4.11 variabel Earning Per Share (EPS) secara statistik menunjukkan hasil Sig. 0,901 lebih kecil dari $a(0,901>0,005)$. Nilai thitung sebesar $-0,125$, sedangkan untuk dapat mengetahui besarnya tabel yaitu dengan melihat $a=0,005$, dalam pengujian hipotesis untuk model regresi, derajat bebas ditentukan dengan rumus $n-2$. Dimana $n=$ banyak observasi, jadi $n-2=35-$ $2=33$ sehingga dapat diperoleh tabelnya sebesar 2,034 artinya thitung $>t_{\text {tabel }}(-0,125<$ 2,034), sehingga $\mathrm{H}_{0}$ diterima dan $\mathrm{H}_{a}$ ditolak dan dapat disimpulkan bahwa variabel Earning Per Share (EPS) secara parsial tidak berpengaruh signifikan terhadap Price Earning Rasio.

\section{PENUTUP}

Berdasarkan dari hasil pembahasan, analisis data, dan pengujian hipotesis 
Pengaruh Debt To Equity Ratio, Return On Equity, Earning Per Share Terhadap Price Earning Ratio Pada Perusahaan Sektor Otomotif yang Terdaftar di Indeks Saham Syariah Indonesia (ISSI) Tahun 2013-

tentang "Pengaruh Debt To Equity Ratio, Return On Equity Ratio, Earning Per Share terhadap Price Earning Ratio pada Perusahaan Sektor Otomotif yang terdaftar di Indeks Saham Syariah Indonesia (ISSI) Tahun 2013-2017", maka dapat ditarik kesimpulan sebagai berikut:

1. Analisis Uji $\mathrm{F}$ diketahui Hal tersebut terbukti dengan nilai $\mathrm{F}_{\text {hitung }}$ sebesar 3,083 yang lebih besar dari $\mathrm{F}_{\text {tabel }}$ pada tingkat signifikansi $5 \%$ yaitu sebesar 2,90 dengan demikian diketahui bahwa $F_{\text {hitung }} 3,083>F_{\text {tabel }} 2,90$. Artinya adalah bahwa variabel independen secara bersama samaberpengaruh signifikan terhadap variabel dependen. Maka hipotesis pertama diterima yaitu DER, ROE dan EPS berpengaruh secara simultan terhadap PER.

2. Analisis Uji-t menunjukan dari variabel Debt To Equity Ratio (DER) secara statistik menunjukkan hasil paling berpengaruh terhadap Price Earning Ratio dengan Sig. 0,045 lebih besar dari $a(0,045>0,005)$. Nilai $t_{\text {hitung }}$ sebesar 2,087 yang lebih besar dari $\mathrm{T}_{\text {tabel }}$ sebesar 2,034, artinya $t_{\text {hitung }}>\mathrm{t}_{\text {tabel }}(0,436<2,034)$. Variabel Return On Equity (ROE) secara statistik menunjukkan Nilai $\mathrm{T}_{\text {hitung }}$ sebesar $-0,571 \mathrm{t}_{\text {tabel }}$ nya sebesar 2,034, artinya $t_{\text {hitung }}<t_{\text {tabel }}(-0,344<2,034)$ sehingga $\mathrm{H}_{0}$ diterima dan $\mathrm{H}_{a}$ ditolak dan dapat disimpulkan bahwa variabel Return On Equity (ROE) secara parsial tidak berpengaruh signifikan terhadap Price Earning Rasio. Variabel Earning Per Share (EPS) secara statistik Nilai $t_{\text {hitung }}$ sebesar $-0,125$ sedangkan $t_{\text {tabel }}$ nya sebesar 2,034 artinya $t_{\text {hitung }}<t_{\text {tabel }}(-0,125<2,034)$, sehingga $\mathrm{H}_{0}$ diterima dan $\mathrm{H}_{\mathrm{a}}$ ditolak dan dapat disimpulkan bahwa variabel Earning Per Share (EPS) secara parsial tidak berpengaruh signifikan terhadap Price Earning Rasio.

\section{DAFTAR PUSTAKA}

Abdul Halim, Manajemen Keuangan Bisnis Konsep dan Aplikasi, Jakarta: PT. Mitra wacana Media, 2015

Burhanuddin, Pasar Modal Syariah, Yogyakarta: UII Press, 2009

Christine Dwi Karya Susilawati, Jurnal Riset dan Manajemen (Universitas Pendidikan Indonesia 2012, Vol. 4)

Danang Sunyoto, Analisis Regresi dan Uji Hipotesis, Yogyakarta:Media Pressindo, 2009 Fatati Nuryana, Statistik Bisnis Jilid 1, Surabaya:Pena Salsabila, 2013

Desak Gede Sari Kusumadewi \& Gede Mertha Sudiartha, "Pengaruh Likuiditas, Dividend Payout Ratio, kesempatan Investasi dan Leverage terhadap Price Earning Ratio pada sektor industry barang konsumsi di Bursa Efek Indonesia periode 2010-2014", (EJurnal Manajemen Unud, 2016), Vol. 5

Dwi Priyanto, Paham analisis Statistik Data dengan SPSS, Yogyakarta: Mediakom

Erlin Yulia Rahma dkk, Analisis Variabel Fundamental yang Berpengaruh terhadap Price Earning Ratio (PER) sebagai Dasar Penilaian Saham pada Perusahaan Automotive and Allied yang Terdaftar di Bursa Efek Indonesia, (Jurnal Aplikasi Manajemen (JAM) Vol 12 No 3, 2014)

Eugene F. Brigham, Manajemen Keuangan Edisi Kedelapan, Jakarta: Erlangga, 2001

Fatati Nuryana, Statistik Bisnis Jilid 1, Surabaya:Pena Salsabila, 2013

Imam Ghozali, Aplikasi Analisis Multivariate Dengan Program IBM SPSS 19, Semarang: Universitas Diponegoro, 2011

Irfan Noor Riza, Panen Dolar Dari Bermain Saham, Yogyakarta: Cemerlang Publishing, 2014 
Irham fahmi, Manajemen Keuangan Perusahaan dan Pasar Modal,Jakarta:Mitra Wacana Media, 2004

Irham Fahmi, Pengantar Pasar Modal, Jakarta: Alfabeta, 2013

irham Fahmi, Analisis Investasi dalam Perspektif Ekonomi dan Politik, Bandung: PT. Refika Aditama, 2006

I Made Sudana, Manajemen Keuangan Perusahaan.Jakarta:Erlangga, 2011

Jonathan Sarwono, IBM SPSS STATISTICS 19, Jakarta: PT Elex Media Komputindo,2011

Kasmir, Analisis Laporan Keuangan, Jakarta: PT. Raja Grafindo Persada, 2014

Khaerul Umam, Pasar Modal dan Praktik Pasar Modal Syariah, Bandung: CV Pustaka Setia, 2013

Latipah ratna sari, "Pengaruh NPM, ROE, EPS terhadap Return Saham pada perusahaan farmasi di BEI".(Jurnal Ilmu dan Riset Mananjemen, 2016), Volume. 5

Lyn \& Aileen, Memahami Laporan Keuangan, PT. indeks, 2008

Ni Iluh Putu Wiagustini, dasar;dasar Manajemen Keuangan, Denpasar: Udayana University Press, 2010

Nor Hadi, Pasar Modal (Acuan Teoritis dan Praktis Investasi di Instrumen Keuangan Pasar Modal), Yogyakarta: Graha ilmu, 2013

Manahan P. Tampubulon, Manajemen Keuangan, Jakarta: Mitra Wacana media, 2013

Mohammad Gani Ghonio, Pengaruh Return On Asset, Return On Equity terhadap Harga saham pada perusahaan manufaktur yang terdaftar di ASEAN periode 2013-2015.

Panji Anogara Dan Piji Pakirti, Pengantar Pasar Modal, Jakarta: Rineka Cipta, 2001

Puspa Damasita, "Pengaruh Faktor Leverage, Earning Growth, Dividen Payout Ratio, Size, dan Return On Equity Terhadap Price Earning Ratio pada Perusahaan Non-Keuangan yang Terdaftar di BEI Periode tahun 2006-2009", (jurnal Ekonomi Fakultas Ekonomi Universitas Diponegoro, 2011).

Santoso, Statistik Multivariat Konsep dan Aplikasi dengan SPSS, Jakarta: PT Elex Media Komputindo, 2010

Sofia Suryani Hakmi, Sri Mangesti Rahayu \& Topowijono, "Analisis Fundamental dengan Pendekatan Price Earning Ratio (PER) untuk Menilai Kewajaran Harga Saham sebagai Dasar Pengambilan Keputusan Investasi (Studi pada Subsektor Semen yang listing di Bursa Efek Indonesia pada tahun 2013-2015)", (Jurnal Administrasi Bisnis Universitas BrawijayaMalang, 2017) Vol. 49

Sugiyono, Metode Penelitian Bisnis, Bandung: Alfabeta, 2012

Syofian Siregar, Metode Penelitian Kuantitatif Dilengkapi Dengan Perbandingan Perhitungan Manual \& SPSS, Jakarta: Kencana, 2013

Tammy Aryanti Putri Suparlan, "Pengaruh Return On Equity (ROE) dan Earning Per Share (EPS) terhadap Harga Saham (Studi kasus pada perusahaan Manufaktur sector Otomotif yang terdaftar di Bursa Efek Indonesia tahun periode 2012-2014)

Tavinayati, yulia Qamariyanti, Hukum Pasar Modal Indonesia, Jakarta: Sinar Grafika, 2013

Vivian Firsera Arisona, Faktor-Faktor yang Mempengaruhi PriceEarning Ratio Pada indeks LQ 45 di bursa efek Indonesia, (Jurnal Ilmu Manajemen, 2013), Vol. 1

Wawan Utomo dkk, Pengaruh Leverage (DER), Price Book Value (PBV), Ukuran Perusahaan (Size), Return On Equity (ROE), Deviden Payout Ratio (DPR) Dan Likuiditas (CR) Terhadap Price Earning Ratio (PER) Pada Perusahaan Manufaktur Yang Listing Di Bei Tahun 2009 - 2014, (Journal Of Accounting, Volume 2 No.2 Maret 2016)

Thomas Sumarsan, Sistem Pengendalian Manajemen, Jakarta: Permata Putri Media, 2010 
Pengaruh Debt To Equity Ratio, Return On Equity, Earning Per Share Terhadap Price Earning Ratio Pada Perusahaan Sektor Otomotif yang Terdaftar di Indeks Saham Syariah Indonesia (ISSI) Tahun 2013-

Tim Penyusunan Pedoman Penulisan Karya Tulis Ilmiyah, Penulisan Karya Tulis Ilmiyah (Pamekasan: STAIN Pres, 2012

Tjiptono Darmadji, Pasar Modal Di Indonesia, edisi 3 (Jakarta: Salemba Empat, 2011

Walten, Charles, C. William dan themin, Akuntansi Keuangan, Jakarta: Penerbit Erlangga, 2013 